\title{
Relationships between tryptophan in serum and CSF, and 5-hydroxyindoleacetic acid in CSF of man: effect of cirrhosis of liver and probenecid administration
}

\author{
S. N. YOUNG ${ }^{1}$, S. LAL, T. L. SOURKES, F. FELDMULLER, \\ A. ARONOFF, AND J. B. MARTIN \\ From the Department of Psychiatry, McGill University, the Departments of Psychiatry and Neurology, \\ Montreal General Hospital, and the Departments of Psychiatry, Medicine, and Gastroenterology, \\ Queen Mary Veterans' Hospital, Montreal, Quebec, Canada
}

SYNOPSIS Tryptophan was measured in the lumbar CSF and serum of patients undergoing neurological investigation (controls) and in patients with hepatic cirrhosis. Samples were taken from the fasting patients at 8.00 a.m. Under these conditions, in the controls the mean CSF, free (nonalbumin-bound) and total serum tryptophan were in the approximate ratio $1: 4: 24$. In this crosssectional study, for the controls, CSF tryptophan was correlated significantly and positively with the total serum but not with the free serum tryptophan. In patients with advanced hepatic cirrhosis the mean CSF tryptophan concentration was greatly elevated. However, the mean total serum tryptophan was unchanged and the free serum tryptophan only slightly elevated. Administration of probenecid, which displaces tryptophan from binding sites on serum albumin, and thereby increases the proportion of serum tryptophan in the free form, did not affect CSF tryptophan.

Work on experimental animals has elucidated some of the factors that control 5-hydroxytryptamine (5-HT) metabolism in the central nervous system (CNS). The rate-limiting enzyme in 5-HT formation is thought to be tryptophan hydroxylase, an enzyme which is not saturated at normal brain tryptophan concentrations (Friedman et al., 1972), suggesting that the brain tryptophan concentration may play a role in controlling 5-HT synthesis. As would be expected in such circumstances, rat brain 5-HT can be increased by administration of even quite small tryptophan loads (Fernstrom and Wurtman, 1971). However, the exact relationship between plasma tryptophan and brain tryptophan, and hence presumably brain 5-HT, has recently been in dispute. Most of the tryptophan in plasma is bound to albumin (McMenamy and Oncley, 1958) and it has been suggested that it is the unbound or free plasma tryptophan which controls

1 Address for reprints: Dr S. N. Young, Laboratory of Neurochemistry, Allan Memorial Institute of Psychiatry, 1025 Pine Avenue West, Montreal, Quebec, Canada H3A 1A1.

(Accepted 24 September 1974.) brain tryptophan (Tagliamonte et al., 1971). Others have suggested that it is the ratio of total plasma tryptophan to the plasma neutral amino acids, leucine, isoleucine, valine, tyrosine, and phenylalanine which controls brain tryptophan (Fernstrom et al., 1973). These neutral amino acids inhibit the transport of tryptophan into brain (Kiely and Sourkes, 1972).

For man, much less is known. A load of tryptophan increases the concentration of the 5-HT metabolite, 5-hydroxyindoleacetic acid (5-HIAA) in the cerebrospinal fluid (CSF); the CSF tryptophan and 5-HIAA are significantly and positively correlated (Ashcroft et al., 1973b). As CSF 5-HIAA is an index of CNS 5-HT metabolism (Moir et al., 1970), this indicates that the tryptophan load is increasing turnover of CNS 5-HT. Although pharmacological doses of tryptophan can affect CNS 5-HT metabolism in this way, it is not known how normal variations in free and total serum tryptophan affect CNS tryptophan and how CNS tryptophan, in turn, affects CNS 5-HT metabolism. In an 
attempt to throw light on these problems we measured tryptophan in serum (free and total), and tryptophan and 5-HIAA in the CSF of patients undergoing investigation. The CSF tryptophan concentration may reflect its concentration in the CNS.

Most of the patients were undergoing neurological investigation. The rest had advanced cirrhosis of the liver, and some of these were in hepatic coma. We investigated the patients with hepatic cirrhosis because work on experimental animals with portocaval shunts has indicated abnormalities in CNS 5-HT metabolism, which may contribute to some of the mental abnormalities associated with hepatic failure (Baldessarini and Fischer, 1973; Curzon et al., 1973). There have been reports that, in the CSF of patients with liver damage, tryptophan is elevated (Müting, 1962; Young et al., 1974). In cases of hepatic coma 5-HIAA is also elevated (Knell et al., 1972; Lal et al., 1974).

For some of the patients, samples were taken before and after the administration of probenecid. Probenecid blocks the transport of acidic amine metabolites, like 5-HIAA, out of CSF. It has been suggested that the increase in the amine metabolite concentration in CSF after probenecid administration is a better index of the turnover of the parent amine in the CNS than their baseline concentrations. However, probenecid also has the effect of displacing tryptophan from binding sites on serum albumin (Lewander and Sjöström, 1973), and so affecting the ratio of free to total serum tryptophan. Thus, probenecid might be a useful tool for investigating how changes in free and total tryptophan affect CSF (and perhaps brain) tryptophan.

\section{METHODS}

All subjects were patients admitted to a general hospital for neuropsychiatric or gastroenterological investigation and treatment. The patients undergoing neuropsychiatric investigation are referred to as controls. Of the patients with advanced cirrhosis, cases 11-20 (Table 4) had significant portosystemic shunting through collateral vessels and a history of hepatic coma. Case 9 had oesophageal varices on gastroscopy but no history of coma. Case 10 had advanced cirrhosis but was without evidence of portosystemic shunting of blood and without history of coma. All patients had been maintained on a normal hospital diet for at least three days before lumbar puncture, except for some of the patients with hepatic cirrhosis who were on a protein restricted diet. These were case 11 (in Table 4) who was on $80 \mathrm{~g}$ protein per day; case 12:60 g per day; case 15: $20 \mathrm{~g}$ per day; cases 16,17, 18, and 19: $40 \mathrm{~g}$ per day; and case 20:10 g per day. Lumbar punctures were performed at 8:00 a.m. after an overnight fast. Subjects remained recumbent after 12:00 midnight on the evening preceding each lumbar puncture to avoid disturbing the CSF gradient of 5-HIAA. None of the subjects was taking drugs known to affect 5-HT metabolism, or containing acetylsalicylic acid, which interferes with the assay of 5-HIAA. Blood samples were taken less than 15 minutes after the CSF.

The probenecid test used was based on that of Olsson and Roos (1968). The first lumbar puncture was performed on day 1 at 8:00 a.m. On days 2 and 3 probenecid, $0.5 \mathrm{~g}$, was administered orally at 6:00 a.m., 12:00 noon, 6:00 p.m., and 12:00 midnight. On day 4 at $4: 30$ a.m. an additional $1.0 \mathrm{~g}$ probenecid was administered and the second CSF sample was taken at 8:30 a.m.

Some of the patients with hepatic cirrhosis were investigated while in hepatic coma and some after recovery from coma. Hepatic coma was graded on an eight-point scale based on the Webster-Davidson classification (1956): $\pm=$ minimal impairment of emotional reactions or mental agility; $1+=$ definite impairment of ability to perform calculations, change in personal tidiness, far-away look, oriented as to time and place; $2+=$ delayed response, confused, oriented to place but not to time; $3+=$ somnolent and disoriented to time and place; $4+=$ marked confusion and drowsiness with slow monosyllabic spoken response; $5+=$ semicomatose with nonspoken responses by groaning and grimacing to stimuli; $6+=$ response only to painful stimuli; $7+=$ no response to painful stimuli, gag and corneal reflexes absent.

5-HIAA was measured fluorometrically. A suitable volume of CSF (2-5 ml) was deproteinized with $1 \mathrm{ml} 10 \% \mathrm{ZnSO}_{4}$ and $1 \mathrm{ml} 0.5 \mathrm{~N} \mathrm{NaOH}$. The supernatant was loaded on a $3 \times 0.5 \mathrm{~cm}$ column of Bio-Rex 5 that had been equilibrated with $10 \mathrm{mM}$ Tris $\mathrm{pH}$ 8.0. The 5-HIAA was eluted with $2.0 \mathrm{ml}$ $2.5 \mathrm{~N} \mathrm{HCl}$ containing $0.01 \%$ ascorbic acid. The fluorescence of this solution was determined as described by Papeschi and McClure (1971).

Tryptophan was determined by the method of Denckla and Dewey (1967). Free serum tryptophan was taken as the tryptophan concentration in an ultrafiltrate of serum. Serum was equilibrated with $5 \% \mathrm{CO}_{2}$ and the ultrafiltration was performed at $37^{\circ}$ using an Amicon propellant-pressurized ultrafiltration cell with UM 10 membranes (nominal molecular 


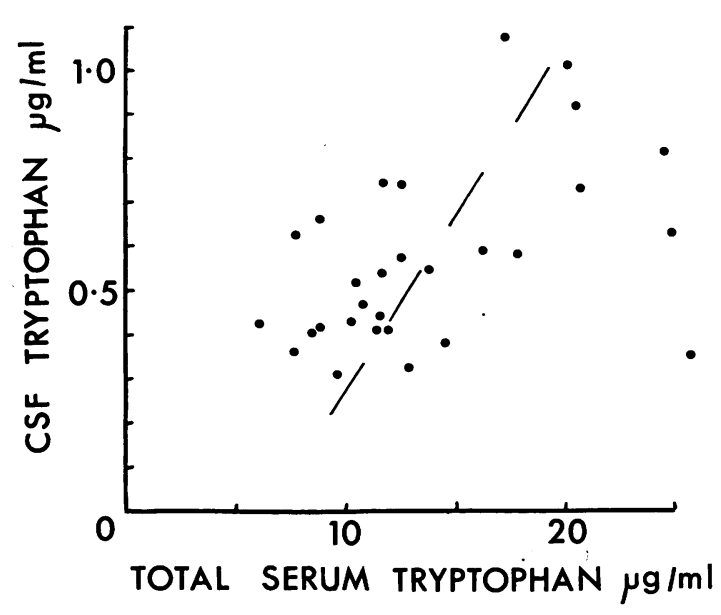

FIG. 1 A plot of total serum tryptophan against CSF tryptophan for 29 controls. Each point represents one patient. The correlation is significant $(r=0.465$; $P<0.05)$.

weight cut-off, 10 000). Blood samples were put on ice immediately after they were taken and the ultrafiltration was performed within two hours.

Serum albumin was measured as part of the SMA 12 analyses by the method of Rutstein et al. (1954) using a Technicon autoanalyzer.

\section{RESULTS}

INTERRELATIONSHIPS IN CONTROLS Table 1 gives
TABLE 1

CONCENTRATIONS OF 5-HIAA IN CSF, AND TRYPTOPHAN IN CSF AND SERUM OF PATIENTS WITH AND WITHOUT CIRRHOSIS OF LIVER*

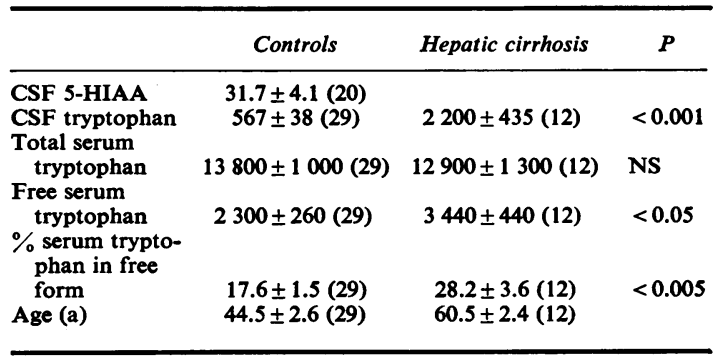

* Values (in $\mathrm{ng} / \mathrm{ml}$ ) are given as mean $\pm S E$ (number of determinations).

The control group consisted of 19 males and 10 females. 5-HIAA was measured in samples from 13 males and seven females. In none of the parameters was there a significant difference between the means obtained with males or females alone. All patients with hepatic cirrhosis were male. NS: $\mathbf{P}>0.05$.

the mean concentration of 5-HIAA and tryptophan found in the controls. Correlations were sought between the variables that were measured, and these have been set out in Table 2. It is clear that 5-HIAA in the CSF is not correlated significantly with any of the forms of tryptophan that were studied (Table 2, section 1).

The mean concentrations of CSF tryptophan, free serum tryptophan, and total serum trypto-

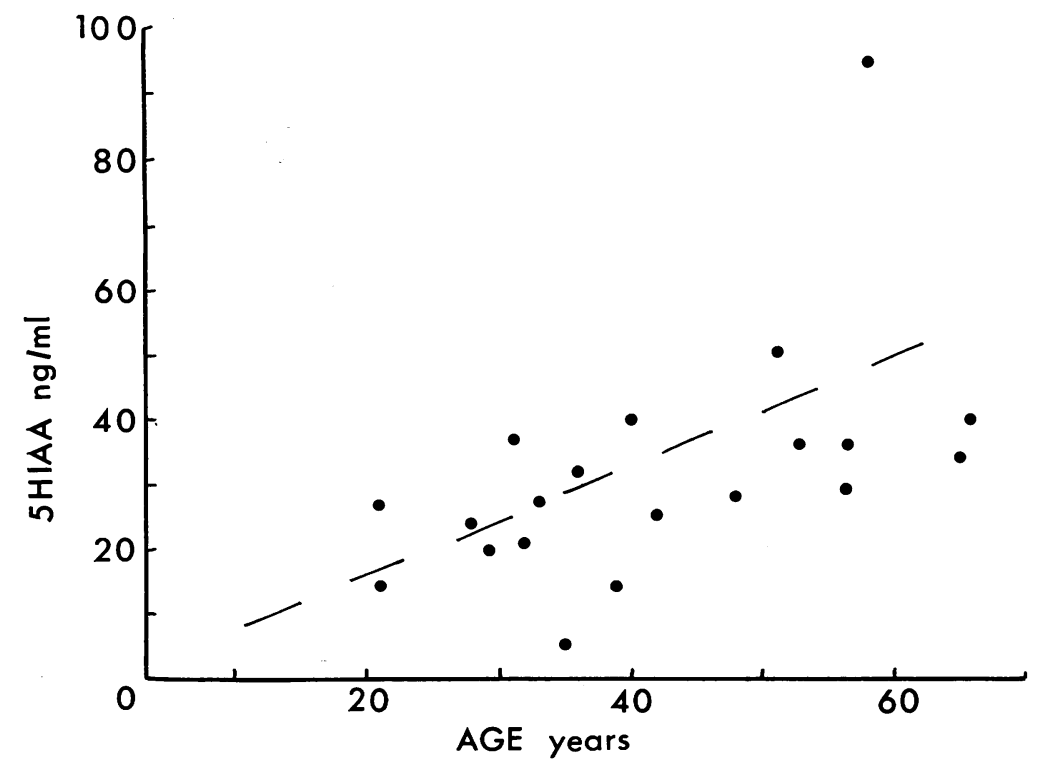

FIG. 2 A plot of CSF 5-HIAA against age for 20 controls. Each point represents one patient. The correlation is significant $(r=0.531 ; P<0.05)$. 
TABLE 2

CORRELATIONS BETWEEN MEASURED VARIABLES

\begin{tabular}{|c|c|c|c|c|}
\hline Variables & Subjects & No. & $r$ & $\boldsymbol{P}$ \\
\hline $\begin{array}{l}\text { 1. CSF 5-HIAA } \\
\text { vs CSF tryptophan } \\
\text { vs total serum tryptophan } \\
\text { vs free serum tryptophan }\end{array}$ & $\begin{array}{l}\text { Controls } \\
\text { Controls } \\
\text { Controls }\end{array}$ & $\begin{array}{l}20 \\
20 \\
20\end{array}$ & $\begin{array}{r}0.166 \\
-0.056 \\
-0.044\end{array}$ & $\begin{array}{l}\text { NS } \\
\text { NS } \\
\text { NS }\end{array}$ \\
\hline $\begin{array}{l}\text { 2. CSF tryptophan } \\
\text { vs total serum tryptophan } \\
\text { vs free serum tryptophan }\end{array}$ & $\begin{array}{l}\text { Controls } \\
\text { Males } \\
\text { Females } \\
\text { Controls }\end{array}$ & $\begin{array}{l}29 \\
19 \\
10 \\
29\end{array}$ & $\begin{array}{r}0.465 \\
0.363 \\
0.633 \\
-0.017\end{array}$ & $\begin{array}{l}<0.05 \\
\text { N.S } \\
\sim 0.05 \\
\text { NS }\end{array}$ \\
\hline $\begin{array}{l}\text { 3. Free serum tryptophan } \\
\text { vs total serum tryptophan } \\
\text { vs } \% \text { serum tryptophan in free form }\end{array}$ & $\begin{array}{l}\text { Controls } \\
\text { Controls }\end{array}$ & $\begin{array}{l}29 \\
29\end{array}$ & $\begin{array}{l}0.436 \\
0.629\end{array}$ & $\begin{array}{l}<0.05 \\
<0.001\end{array}$ \\
\hline $\begin{array}{l}\text { 4. Age } \\
\text { vs CSF 5-HIAA } \\
\text { vs CSF tryptophan }\end{array}$ & $\begin{array}{l}\text { Controls } \\
\text { Males } \\
\text { Females } \\
\text { Controls } \\
\text { Males } \\
\text { Females }\end{array}$ & $\begin{array}{r}20 \\
13 \\
7 \\
29 \\
19 \\
10\end{array}$ & $\begin{array}{l}0.531 \\
0.567 \\
0.688 \\
0.250 \\
0.461 \\
0.044\end{array}$ & $\begin{array}{c}<0.05 \\
<0.05 \\
\text { NS } \\
\text { NS } \\
\sim 0.05 \\
\text { NS }\end{array}$ \\
\hline $\begin{array}{l}\text { 5. Serum albumin } \\
\text { vs } \% \text { serum tryptophan in free form }\end{array}$ & $\begin{array}{l}\text { Hepatic } \\
\text { cirrhosis }\end{array}$ & 10 & -0.243 & NS \\
\hline
\end{tabular}

NS: $\mathrm{P}>0.05$.

phan in control subjects are in the approximate ratio $1: 4: 24$. However, relative concentrations of CSF tryptophan and free serum tryptophan vary widely. For example, in three patients with low free serum tryptophan $(460,700$, and 980 $\mathrm{ng} / \mathrm{ml}$ ), the values in each case were lower than for CSF tryptophan $(660,730$, and $1010 \mathrm{ng} / \mathrm{ml}$, respectively).

Perhaps because of this large variation it was not possible to demonstrate a significant correlation between free serum tryptophan and CSF tryptophan concentrations. However, total serum

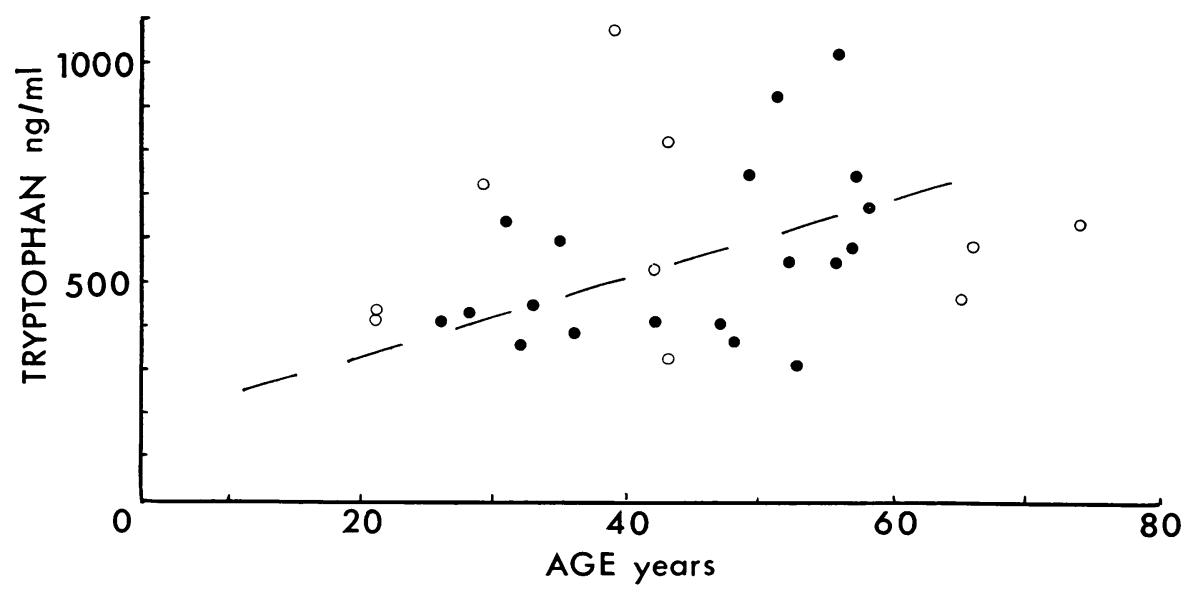

FIG. 3 A plot of CSF tryptophan against age for 19 males (O) and 10 females (O). The regression line shown is that calculated for the males. The correlation is significant $(r=0.461 ; P \sim 0.05)$. 
TABLE 3

TRYPTOPHAN IN SERUM AND CSF OF PATIENTS WITH CIRRHOSIS IN AND NOT IN COMA*

\begin{tabular}{lccc}
\hline & No coma & In coma & $P$ \\
\hline $\begin{array}{l}\text { CSF tryptophan } \\
\text { Total serum } \\
\text { tryptophan }\end{array}$ & $1750 \pm 280(6)$ & $2590 \pm 820(6)$ & NS \\
$\begin{array}{l}\text { Free serum } \\
\text { tryptophan }\end{array}$ & $3200 \pm 850(6)$ & $3680 \pm 320(6)$ & NS \\
$\begin{array}{l}\text { \% Serum trypto- } \\
\text { phan in free } \\
\text { form }\end{array}$ & $20.3 \pm 3.6(6)$ & $36.1 \pm 4.7(6)$ & $<0.025$ \\
$\begin{array}{l}\text { Serum albumin } \\
\text { (6.20 }\end{array}$ & $3.200 .10(6)$ & $2.40 \pm 0.27(5)$ & $<0.025$ \\
\hline
\end{tabular}

* Values (in $\mathrm{ng} / \mathrm{ml}$ ) are given as mean $\pm \mathrm{SE}$ (number of determinations). For albumin, results are in $\mathrm{g} / \mathrm{dl}$.

NS: $\mathbf{P}>\mathbf{0 . 0 5}$.

tryptophan was significantly and positively correlated with the CSF tryptophan level (Fig. 1 and Table 2, section 2). This correlation held for the females in the group, but not for the males.

The free serum tryptophan concentration was correlated with the total serum tryptophan and even more strongly with the percentage of serum tryptophan in the free form (Table 2, section 3). CSF 5-HIAA is correlated significantly and positively with age (Fig. 2 and Table 2, section 4). CSF tryptophan is similarly correlated with age $(P \sim 0.05)$ but only for the males in the group (Fig. 3 and Table 2, section 4).

TRYPTOPHAN IN HEPATIC CIRRHOSIS In hepatic cirrhosis we found the mean CSF tryptophan was elevated almost fourfold over the controls (Table 1). The mean free serum tryptophan was significantly higher than in controls but the total serum tryptophan was approximately the same in the two groups. The percentage of serum tryptophan in the free form was significantly greater in hepatic cirrhosis and serum albumin concentrations $(2.78 \pm 0.20 \mathrm{~g} / \mathrm{dl})$ were, as expected, below the normal range (3.5-5.1 g/dl).

When the group with hepatic cirrhosis is divided into those in and out of coma (Table 3), the only significant differences between the two groups are in the percentage of serum tryptophan

TABLE 4

TRYPTOPHAN IN SERUM AND CSF OF CONTROLS AND PATIENTS WITH HEPATIC CIRRHOSIS: EFFECT OF PROBENECID*

\begin{tabular}{|c|c|c|c|c|c|c|c|c|c|c|c|c|c|c|}
\hline \multirow[t]{2}{*}{ Patient } & \multirow{2}{*}{$\begin{array}{l}\text { Age } \\
\text { (a) }\end{array}$} & \multirow[t]{2}{*}{ Sex } & \multirow{2}{*}{$\begin{array}{l}\text { Hepatic } \\
\text { cirrhosis }\end{array}$} & \multirow{2}{*}{$\begin{array}{c}\text { History } \\
\text { of } \\
\text { coma }\end{array}$} & \multicolumn{2}{|c|}{ Degree of coma } & \multicolumn{2}{|c|}{ CSF tryptophan } & \multicolumn{2}{|c|}{$\begin{array}{l}\text { Total serum } \\
\text { tryptophan }\end{array}$} & \multicolumn{2}{|c|}{$\begin{array}{l}\text { Free serum } \\
\text { tryptophan }\end{array}$} & \multicolumn{2}{|c|}{$\begin{array}{l}\% \text { Serum trypto- } \\
\text { phan in free form }\end{array}$} \\
\hline & & & & & Ist L.P. & 2nd L.P. & Initial & $\begin{array}{c}\% \\
\text { change }\end{array}$ & Initial & $\begin{array}{c}\% \\
\text { change }\end{array}$ & Initial & $\begin{array}{c}\% \\
\text { change }\end{array}$ & Initial & $\begin{array}{c}\% \\
\text { change }\end{array}$ \\
\hline $\begin{array}{l}1 \\
2 \\
3 \\
4 \\
5 \\
6 \\
7 \\
8\end{array}$ & $\begin{array}{l}52 \\
33 \\
51 \\
66 \\
48 \\
21 \\
42 \\
52\end{array}$ & $\begin{array}{l}\mathbf{M} \\
\mathbf{M} \\
\mathbf{M} \\
\mathbf{F} \\
\mathbf{M} \\
\mathbf{F} \\
\mathbf{M} \\
\mathbf{F}\end{array}$ & & & & & $\begin{array}{l}544 \\
442 \\
921 \\
582 \\
365 \\
415 \\
407 \\
465\end{array}$ & $\begin{array}{l}-8.5 \\
+10 \\
-33 \\
+42 \\
-17 \\
+13 \\
-5 \\
-5\end{array}$ & $\begin{array}{r}13700 \\
11500 \\
20400 \\
17800 \\
7720 \\
8820 \\
8890 \\
10000\end{array}$ & $\begin{array}{l}-31 \\
-21 \\
-56 \\
-37 \\
-15 \\
-24 \\
-31 \\
-36\end{array}$ & $\begin{array}{ll}2 & 840 \\
2 & 080 \\
2 & 030 \\
3 & 620 \\
2 & 200 \\
2 & 100 \\
1 & 120 \\
1 & 290\end{array}$ & $\begin{array}{l}+42 \\
+0.7 \\
+60 \\
+30 \\
-17 \\
-10 \\
+52 \\
+33\end{array}$ & $\begin{array}{r}20.7 \\
18.1 \\
9.9 \\
20.3 \\
28.5 \\
23.8 \\
12.6 \\
12.9\end{array}$ & $\begin{array}{l}+107 \\
+27 \\
+260 \\
+108 \\
-15 \\
+18 \\
+128 \\
+108\end{array}$ \\
\hline $\begin{array}{r}9 \\
10 \\
11 \\
12 \\
13 \\
14\end{array}$ & $\begin{array}{l}63 \\
70 \\
55 \\
65 \\
62 \\
51\end{array}$ & $\begin{array}{l}\mathbf{M} \\
\mathbf{M} \\
\mathbf{M} \\
\mathbf{M} \\
\mathbf{M} \\
\mathbf{M}\end{array}$ & $\begin{array}{l}+ \\
+ \\
+ \\
+ \\
+ \\
+\end{array}$ & $\begin{array}{l}- \\
- \\
+ \\
+ \\
+ \\
+\end{array}$ & $\begin{array}{l}\mathbf{0} \\
\mathbf{0} \\
\mathbf{0} \\
\mathbf{0} \\
\mathbf{0} \\
\mathbf{0}\end{array}$ & $\begin{array}{l}0 \\
0 \\
0 \\
0 \\
0 \\
0\end{array}$ & $\begin{array}{r}2480 \\
2460 \\
1910 \\
1160 \\
792 \\
1680\end{array}$ & $\begin{array}{l}+15 \\
+7.3 \\
+12 \\
+4.3 \\
+0.6 \\
+1.1\end{array}$ & $\begin{array}{r}21800 \\
17000 \\
17900 \\
12600 \\
6320 \\
14600\end{array}$ & $\begin{array}{l}-29 \\
-39 \\
-33 \\
-32 \\
+31 \\
-44\end{array}$ & $\begin{array}{ll}6 & 300 \\
3 & 000 \\
5 & 140 \\
2 & 000 \\
1 & 420 \\
1 & 310\end{array}$ & $\begin{array}{l}+15 \\
+72 \\
+7 \\
+9.1 \\
+139 \\
+75\end{array}$ & \begin{tabular}{r|}
28.8 \\
17.6 \\
28.7 \\
15.8 \\
22.5 \\
8.9
\end{tabular} & $\begin{array}{l}+62 \\
+180 \\
+59 \\
+61 \\
+82 \\
+215\end{array}$ \\
\hline $\begin{array}{l}15 \\
16 \\
17 \\
18 \\
19 \\
20\end{array}$ & $\begin{array}{l}\mathbf{5 7} \\
\mathbf{7 9} \\
\mathbf{6 2} \\
\mathbf{5 1} \\
\mathbf{5 2} \\
\mathbf{5 9}\end{array}$ & $\begin{array}{l}\mathbf{M} \\
\mathbf{M} \\
\mathbf{M} \\
\mathbf{M} \\
\mathbf{M} \\
\mathbf{M}\end{array}$ & $\begin{array}{l}+ \\
+ \\
+ \\
+ \\
+ \\
+\end{array}$ & $\begin{array}{l}+ \\
+ \\
+ \\
+ \\
+ \\
+\end{array}$ & $\begin{array}{l}1 \\
3 \\
3 \\
4 \\
5 \\
4\end{array}$ & $\begin{array}{l}0 \\
3 \\
4\end{array}$ & $\begin{array}{r}2180 \\
912 \\
1470 \\
766 \\
5270 \\
4930\end{array}$ & $\begin{array}{l}-36 \\
+3.4 \\
+6.8\end{array}$ & $\begin{array}{r}10300 \\
11100 \\
8800 \\
6800 \\
12200 \\
15000\end{array}$ & $\begin{array}{l}-37 \\
-30 \\
-7.9\end{array}$ & $\begin{array}{ll}4 & 480 \\
4 & 170 \\
4480 \\
2722 \\
2926 \\
3328\end{array}$ & $\begin{array}{l}-2.4 \\
+2.4 \\
+16\end{array}$ & $\begin{array}{l}43.5 \\
37.5 \\
50.9 \\
40.0 \\
22.3 \\
22.1\end{array}$ & $\begin{array}{l}+55 \\
+47 \\
+26\end{array}$ \\
\hline
\end{tabular}

* Values are given in $\mathrm{ng} / \mathrm{ml}$ and $\%$ change after probenecid administration.

In the control group (patients $1-8$ ) probenecid caused a significant decrease in total serum tryptophan $(P<0.01)$ and a significant increase in the $\%$ serum tryptophan in the free form $(P<0.01)$.

In the group with hepatic cirrhosis (patients 9-17) probenecid caused a significant decrease in total serum tryptophan (P<0.05) and significant increases in free serum tryptophan $(P<0.01)$ and $\%$ serum tryptophan in free form $(P<0.01)$. 
in the free form and in the concentration of serum albumin. However, there is no significant correlation between these two parameters for the whole group with hepatic cirrhosis (Table 2, section 5).

CSF 5-HIAA concentrations in hepatic cirrhosis have been reported on in detail elsewhere (Lal et al., 1974).

TRYPTOPHAN AFTER PROBENECID Table 4 shows the changes produced by administering probenecid to eight controls and nine patients with hepatic cirrhosis. In both groups there is a significant decrease in total serum tryptophan and a significant increase in the percentage of serum tryptophan in the free form, but no mean change in the concentration of tryptophan in the CSF. In addition, probenecid causes a significant increase in the free serum tryptophan concentration in those with cirrhosis of the liver.

\section{DISCUSSION}

INTERRELATIONSHIPS IN CONTROLS Results in Table 2, section 1 , indicate that CSF 5-HIAA is not correlated significantly with the tryptophan concentration in either CSF or serum. If the brain tryptophan concentration does control brain 5-HT turnover in physiological circumstances in man, it might be expected that the brain tryptophan concentration would be related to CSF 5-HIAA, which is an index of CNS 5-HT metabolism (Moir et al., 1970). It has been suggested that the CSF is a sink for brain amino acids (Wurtman and Fernstrom, 1972). Thus, CSF tryptophan may reflect CNS tryptophan concentrations. Therefore, a correlation might be expected between the CSF tryptophan and the CSF 5-HIAA concentrations. However, no such correlation exists. Furthermore, there is no correlation between CSF 5-HIAA and either the free or total serum tryptophan concentrations, both of which have been proposed as factors that control brain tryptophan. The lack of any relationship between these parameters may indicate that, within normal fluctuations, the concentration of brain tryptophan is not a major determining factor in brain 5-HT metabolism. Alternatively, it may be that CSF 5-HIAA concentration is not a sensitive enough index of
CNS 5-HT turnover to reflect physiological variations in 5-HT synthesis.

Table 2, section 2 shows the correlations between CSF tryptophan and both the free and total serum tryptophan concentrations. Our finding that CSF tryptophan is significantly correlated with total serum tryptophan (Fig. 1) but not with free serum tryptophan seemingly answers one of the questions this study was designed to answer. However, a significant correlation does not necessarily imply a causative relationship-that is, that total serum tryptophan is a factor controlling CSF tryptophan and that the concentration of the free serum tryptophan is unimportant. The correlation, in this type of cross-sectional study, may merely reflect the fact that some individuals have high, and some low, concentrations of this amino acid in their extracellular fluids, including plasma and CSF. Even in such a situation it could be fluctuations in free serum tryptophan that control variations in CSF tryptophan, and longitudinal studies in given individuals, where intrinsic variations in tryptophan concentrations may be less than between individuals, are therefore, desirable. In fact, a recent study (Pérez-Cruet et al., 1974) provides some information along these lines. CSF and blood samples were taken before and after a meal. In the postprandial samples free serum tryptophan and CSF tryptophan concentrations were both lower than in the initial sample, while total serum tryptophan increased.

Table 2, section 3 shows that the free serum tryptophan concentration correlates more closely with the percentage of serum tryptophan in the free form than with the total serum tryptophan. The percentage in the free form will depend on the extent to which tryptophan is displaced from its binding sites on serum albumin. The displacement is thought to be due mainly to non-esterified free fatty acids in the serum (McMenamy, 1963). Thus, our results suggest that displacement of tryptophan from albumin binding sites could be a more important factor in controlling the free serum tryptophan concentration than the total amount of tryptophan present in the serum.

The relationships between the age of the patients and CSF 5-HIAA and tryptophan are shown in Table 2 , section 3 . We find a significant 
increase in CSF 5-HIAA with increasing age (Fig. 2). The increase, like that found by Gottfries et al. (1971), was linear. However, it is possible that we did not observe the U-shaped curve obtained by Bowers and Gerbode (1968) because only four of the patients were less than 30 years old. The correlation of CSF tryptophan and age is on the borderline of significance when only the males in the group are considered (Fig. 3). No such relationship has yet been reported, although Ashcroft et al. (1973a) found a significant correlation of CSF tryptophan and age, after a tryptophan load. Further work will be necessary to confirm such a relationship with baseline concentrations of tryptophan.

TRYPTOPHAN IN HEPATIC CIRRHOSIS The concentration of tryptophan found in the CSF of patients with hepatic cirrhosis is too high to be accounted for by the greater age of the cirrhotic group, compared with controls (Table 1). There have been reports of elevated brain tryptophan in animals with experimental models of liver failure. Thus, in dogs, during acute hepatic coma, the concentrations of most brain amino acids rise; the levels of the aromatic amino acids histidine, phenylalanine, tyrosine, and tryptophan increase to the greatest extent (Mattson et al., 1970). In pigs in acute hepatic failure there was an increase in brain tryptophan concentration and a raised turnover rate of 5-HT (Curzon et al., 1973). In this acute experiment the rise in brain tryptophan was associated with an increase in free serum tryptophan.

The same may be true in patients with fulminant hepatic failure where free serum tryptophan is elevated eight-fold (Knell et al., 1974). In the chronic cases we have studied this is not true, as the increase in the mean free serum concentration $(50 \%)$ is negligible compared with the increase in CSF tryptophan (308\%). The cause of the elevated CSF tryptophan in our chronic cases of hepatic cirrhosis is unknown.

A role for tryptophan has been suggested in hepatic coma. Thus, tryptophan loads produced marked neurological symptoms in dogs with an Eck fistula, whereas glycine, glutamic acid, leucine, methionine, and phenylalanine did not (Ogihara et al., 1966). Also in rats with diversion of the portal blood flow, brain tryptophan and
5-HT were elevated (Baldessarini and Fischer, 1973). L-Dopa, which has an arousal effect on some patients (Parkes et al., 1970), caused 5-HT to decline in these rats. This led to the suggestion (Baldessarini and Fischer, 1973) that the elevated brain tryptophan causes an increase, in 5-HT which then acts as 'false neurotransmitter' in non-serotonergic neurones, thus contributing to some of the abnormalities associated with clinical hepatic failure. However, our results are not consistent with this hypothesis. When comparing patients in and out of coma we find no significant difference in CSF tryptophan concentrations (Tables 3 and 4) and, as reported elsewhere (Lal et al., 1974), we find no difference in CNS 5-HT turnover as assessed by the changes in concentration of 5-HIAA in the CSF caused by probenecid ingestion. Thus, although CSF tryptophan concentrations in patients with hepatic cirrhosis are very high, there is no increase in the rate of turnover of 5-HT in the CNS (Lal et al., 1974).

Our results disagree with certain previously published reports. Thus, Müting (1962) found $a_{\infty}$ significant elevation of CSF tryptophan in aO group in hepatic coma, compared with those $\overrightarrow{0}$ with liver disease, but without coma. However, these results were obtained with an amino acid analyser and the mean value for normal adults was four times that obtained for our controls. Thus, the amino acid analyser probably does not give as reliable results for tryptophan in CSF as the specific method of Denckla and Dewey (1967).

Hirayama (1971) noted elevated total serum tryptophan in patients with hepatic encephalopathy and coma, but we again have found no significant differences in total serum tryptophan when comparing those in and out of coma (Table 3), although there may be a tendency for total serum tryptophan to decline in hepatic coma.

The percentage of serum tryptophan in the free form is significantly higher in those with cirrhosis than in controls (Table 1). The difference is due entirely to those in coma, as the group out of coma have approximately the same percentage as controls (Table 3). Comparing those in and out of coma, we also find that the former have a lower serum albumin. Thus, there 
will be a smaller number of binding sites for tryptophan in the serum, and the percentage in the free form will be greater. However, the correlation between the percentage of serum tryptophan in the free form and serum albumin, although inverse, does not attain statistical significance for the 10 cases of hepatic cirrhosis in this study (Table 2, section 5).

Part of the increase in the percentage of free serum tryptophan may be due to an elevation in free fatty acids. Free fatty acids are elevated in the plasma in a variety of liver disorders (Mortiaux and Dawson, 1961) and short chain fatty acids, which are particularly elevated in hepatic coma, have been implicated as one possible cause of coma (Zieve, 1966).

TRYPTOPHAN AFTER PROBENECID Table 4 shows the effects on CSF and serum tryptophan concentrations of administering probenecid over three days. The procedure used (see section on Methods) is designed to maintain a fairly constant concentration of probenecid over the three days. Thus, these data would show if prolonged alterations in serum tryptophan concentrations affect CSF tryptophan.

We found that probenecid, which displaced tryptophan from binding sites on serum albumin, caused an increase in the percentage of tryptophan in the free form. Lewander and Sjöström (1973) observed that this increase occurs without a significant change in the total serum tryptophan. On the other hand, both we and van Praag et al. (1973) found a significant decrease in the total serum tryptophan. Changes in the free portion were very variable. The reasons for these discrepancies are unknown. In our present study there was no consistent or significant change in CSF tryptophan on probenecid administration. Nor, in individual cases, was there any relationship between the changes in CSF tryptophan, total serum tryptophan, or free serum tryptophan. Thus, our data on probenecid administration do not provide support for the view that either free or total serum tryptophan is the main factor controlling CSF tryptophan over a period of days. Nor can we say that our data provide support for the suggestion (Lewander and Sjöström, 1973) that probenecid increases the rate of brain 5-HT synthesis by increasing the availability of its precursor.
This investigation received financial support from the Medical Research Council (Canada) through grants to T. L. Sourkes and S. Lal.

\section{REFERENCES}

Ashcroft, G. W., Blackburn, I. M., Eccleston, D., Glen, A. I. M., Hartley, W., Kinloch, N. E., Lonergan, M., Murray, L. G., and Pullar, I. A. (1973a). Changes on recovery in the concentrations of tryptophan and the biogenic amine metabolites in the cerebrospinal fluid of patients with affective illness. Psychological Medicine, 3, 319-325.

Ashcroft, G. W., Crawford, T. B. B., Cundall, R. L., Davidson, D. L., Dobson, J., Dow, R. C., Eccleston, D., Loose, R. W., and Pullar, I. A. (1973b). 5-Hydroxytryptamine metabolism in affective illness: the effect of tryptophan administration. Psychological Medicine, 3, 326-332.

Baldessarini, R. J., and Fischer, J. E. (1973). Serotonin metabolism in rat brain after surgical diversion of the portal venous circulation. Nature New Biology, 245, 25-27.

Bowers, M. B., Jr, and Gerbode, F. A. (1968). Relationship of monoamine metabolites in human cerebrospinal fluid to age. Nature, 219, 1256-1257.

Curzon, G., Kantamaneni, B. D., Winch, J., Rojas-Bueno, A., Murray-Lyon, I. M., and Williams, R. (1973). Plasma and brain tryptophan changes in experimental acute hepatic failure. Journal of Neurochemistry, 21, 137-145.

Denckla, W. D., and Dewey, H. K. (1967). The determination of tryptophan in plasma, liver, and urine. Journal of Laboratory and Clinical Medicine, 69, 160-169.

Fernstrom, J. D., and Wurtman, R. J. (1971). Brain serotonin content; physiological dependence on plasma tryptophan levels. Science, 173, 149-152.

Fernstrom, J. D., Larin, F., and Wurtman, R. J. (1973). Correlations between brain tryptophan and plasma neutral amino acid levels following food consumption in rats. Life Sciences, 13, 517-524.

Friedman, P. A., Kappelman, A. H., and Kaufman, S. (1972). Partial purification and characterization of tryptophan hydroxylase from rabbit hindbrain. Journal of Biological Chemistry, 247, 4165-4173.

Gottfries, C. G., Gottfries, I., Johansson, B., Olsson, R., Persson, T., Roos, B.-E., and Sjöström, R. (1971). Acid monoamine metabolites in human cerebrospinal fluid and their relations to age and sex. Neuropharmacology, 10, 665672.

Hirayama, C. (1971). Tryptophan metabolism in liver disease. Clinica Chimica Acta, 32, 191-197.

Kiely, M., and Sourkes, T. L. (1972). Transport of Ltryptophan into slices of rat cerebral cortex. Journal of Neurochemistry, 19, 2863-2872.

Knell, A. J., Pratt, O. E., Curzon, G., and Williams, R. (1972). Changing ideas in hepatic encephalopathy. In Eighth Symposium on Advanced Medicine, pp. 156-170. Edited by G. Neale. Pitman: London.

Knell, A. J., Davidson, A. R., Williams, R., Kantamaneni, B. D., and Curzon, G. (1974). Dopamine and serotonin metabolism in hepatic encephalopathy. British Medical Journal, 1, 549-551.

Lal, S., Aronoff, A., Garelis, E., Sourkes, T. L., Young, S. N., and de la Vega, C. E. (1975). Cerebrospinal fluid homovanillic acid, 5-hydroxyindoleacetic acid, lactic acid and $\mathrm{pH}$ before and after probenecid in hepatic coma. Clinical Neurosurgery, 22, 142-154.

Lewander, T., and Sjöström, R. (1973). Increase in the plasma concentration of free tryptophan caused by probenecid in humans. Psychopharmacologia, 33, 81-86. 
McMenamy, R. H. (1963). Association of indole analogues to defatted human serum albumin. Archives of Biochemistry and Biophysics, 103, 409-417.

McMenamy, R. H., and Oncley, J. L. (1958). The specific binding of L-tryptophan to serum albumin. Journal of Biological Chemistry, 233, 1436-1447.

Mattson, W. J., Jr, Iob, V., Sloan, M., Coon, W. W., Turcotte, J. G., and Child, C. G., III (1970). Alterations of individual free amino acids in brain during acute hepatic coma. Surgery, Gynecology and Obstetrics, 130, 263-266.

Moir, A. T. B., Ashcroft, G. W., Crawford, T. B. B., Eccleston, D., and Guldberg, H. C. (1970). Cerebral metabolites in cerebrospinal fluid as a biochemical approach to the brain. Brain, 93, 357-368.

Mortiaux, A., and Dawson, A. M. (1961). Plasma free fatty acid in liver disease. Gut, 2, 304-309.

Müting, D. (1962). Changes in the free amino acid composition of cerebrospinal fluid in liver disease. Proceedings of the Society of Experimental Biology and Medicine, 110, 620 622.

Ogihara, K., Mozai, T., and Hirai, S. (1966). Tryptophan as cause of hepatic coma. New England Journal of Medicine, 275, 1255-1256.

Olsson, R., and Roos, B. E. (1968). Concentrations of 5-hydroxyindoleacetic acid and homovanillic acid in the cerebrospinal fluid after treatment with probenecid in patients with Parkinson's disease. Nature, 219, 502-503.

Papeschi, R., and McClure, D. J. (1971). Homovanillic acid and 5-hydroxyindoleacetic acid in cerebrospinal fluid of depressed patients. Archives of General Psychiatry, 25, 354358.
Parkes, J. D., Sharpstone, P., and Williams, R. (1970). Levodopa in hepatic coma. Lancet, $2,1341-1343$.

Pérez-Cruet, J., Chase, T. N., and Murphy, D. L. (1974). Dietary regulation of brain tryptophan metabolism by plasma ratio of free tryptophan and neutral amino acids in humans. Nature, 248, 693-695.

Praag H. M., van, Flentge, F., Korf, J., Dols, L. C. W., and Schut, T. (1973). The influence of probenecid on the metabolism of serotonin, dopamine and their precursors in man. Psychopharmacologia, 33, 141-151.

Rutstein, D. D., Ingenito, E. F., and Reynolds, W. E. (1954). The determination of albumin in human blood plasma and serum. A method based on the interaction of albumin with an anionic dye-2-(4'-hydroxy-benzeneazo) benzoic acid. Journal of Clinical Investigation, 33, 211-221.

Touriamonte, A., Biggio, G., and Gessa, G. L. (1971). Possible role of 'free' plasma tryptophan in controlling brain tryptophan concentrations. Rivista di Farmacologia $e$ Terapia, 2, 251-255.

Webster, L. T., Jr, and Davidson, C. S. (1956). The effect of sodium glutamate on hepatic coma. Journal of Clinical Investigation, 35, 191-199.

Wurtman, R. J., and Fernstrom, J. D. (1972). L-Tryptophan, L-tyrosine, and the control of brain monoamine biosynthesis. In Perspectives in Neuropharmacology, p. 165. Edited by S. H. Snyder. Oxford University Press.

Young, S. N., Garelis, E., Lal, S., Martin, J. B., MolinaNegro, P., Ethier, R., and Sourkes, T. L. (1974). Tryptophan and 5-hydroxyindoleacetic acid in human cerebrospinal fluid. Journal of Neurochemistry, 22, 777-779.

Zieve, L. (1966). Pathogenesis of hepatic coma. Archives of Internal Medicine, 118, 211-223. 